\title{
MOBILISASI DINI DALAM PROSES PENYEMBUHAN LUKA SECTIOCAESAREA PADA IBU POST PARTUM DI RS DEWI SARTIKA
}

\author{
IRMAYANTI \\ Akademi Kebidanan Konawe, Jl. DII. Panjaitan, No. 217, Kel. Tuoy, Kec. Unaaha, Kab. Konawe \\ Prov. Sulawesi Tenggara, 085241767787 \\ E-mail : irmayanti.m.kes@gmail.com
}

\begin{abstract}
ABSTRAK
Sectio Caesarea (SC) adalah Salah satu cara penanganan komplikasi persalinan. Berdasarkan wawancara yang dilakukan kepada petugas kesehatan di Rumah Sakit Dewi Sartika, mobilisasi dini dilaksanakan pada semua pasien post operasi SC selama 1-7 hari. Petugas kesehatan menyatakan, hari 1-3 pasien masih takut untuk melakukan mobilisasi. Banyak pasien yang mau melakukan mobilisasi di hari kelima. Kurangnya kesadaran ibu melakukan mobilisasi dini memungkinkan penyembuhan luka terhambat. Oleh karena itu, perlu dilakukan penelitian mengenai hubungan antara mobilisasi dini dengan proses penyembuhan luka sectio caesarea pada ibu post partum". Jenis penelitian yang digunakan adalah kuantitatif analitik dengan pendekatan studi cross sectional. Dari 33 sampel, proses penyembuhan luka section caesarea cepat sebanyak 19 (57.6\%), lambat sebanyak 14 (42.4\%) responden. Sedangkan mobilisasi dini baik sebanyak 21 (63.6\%),

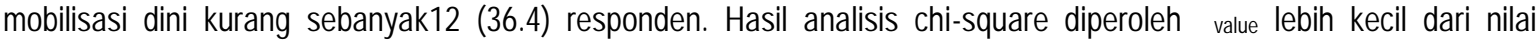
$(0,03<0,05)$. Terdapat hubungan antara Mobilisasi Dini dengan Proses Penyembuhan Luka Section Caesarea pada Ibu Post Partum di Rumah Sakit Dewi Sartika.
\end{abstract}

kata kunci : mobilisasi dini; proses penyembuhan luka; sectio caesarea;

\begin{abstract}
Sectio Caesarea (SC) is one way to treat labor complications. Based on interviews conducted with health workers at Dewi Sartika Hospital, early mobilization was carried out in all patients post SC surgery for 1-7 days. Health workers say, 1-3 days the patient is still afraid to mobilize. Many patients want to mobilize on the fifth day. Lack of awareness of mothers to do early mobilization allows healing of obstructed wounds. Therefore, it is necessary to do research on "The Relationship between Early Mobilization and the Healing Process of Sectio Caesarea in Post Partum Mothers". The type of research used was quantitative analytic with cross sectional study approach of the 33 samples, the wound healing process of the caesarean section was 19 (57.6\%), slow as 14 (42.4\%) respondents. While good early mobilization is 21 (63.6\%), early mobilization is less than $12(36.4)$ respondents. The results of the chi-square analysis obtained $\rho$ value is smaller than the value of a $(0,03<0,05)$. There is a relationship between Early Mobilization and Wound Section Caesarea in Post-Partum at Dewi Sartika Hospital.
\end{abstract}

Keywords : early mobilization; wound healing process; sectio caesarea; 


\section{LATAR BELAKANG}

Hamil dan melahirkan merupakanperistiwa luar biasa yang terjadi sepanjang siklus hidup perempuan, dimana janin dikeluarkan melalui proses persalinan. Masa bersalin merupakan periode kritis bagi ibu hamil. Beberapa komplikasi yang menyertai persalinan seperti plasenta previa, panggul sempit, kelainan his, atonia uteri, dan sebagainya (Wiknjosastro, 2012).

Di Dunia komplikasi persalinan dapat meningkatkan resiko kematian ibu dan janin. Pada tahun 2015 Lebih dari 99\% kematian ibu terjadi di negara-negara berpenghasilan rendah dan menengah yaitu sekitar 302.000 jiwa, 201.000 kasus terjadi di sub-Sahara Afrika dan 66.000 kasus terjadi di Asia Selatan, Prioritas utama Sustainable Development Goals (SDGs)adalah mengurangi rasio kematian ibu (Maternal Mortality Rate) dunia menjadi kurang dari 70 per 100.000 kelahiran hidup pada tahun 2030 (World Health Organization, 2018).

Apabila terjadi komplikasi saat proses persalinan perlu dilakukan tindakan medis segera sebagai upaya untuk menyelamatkan ibu dan bayi. Salah satu cara penanganan komplikasi persalinan yaitu proses persalinan dilakukan dengan operasi Sectio Caesarea (SC).

Setelah operasi SC efek anestesi akan hilang dan ibu akan mengalami nyeri pada luka insisi abdomen, potensi terjadinya trombosis dan tromboemboli, infeksi dan sebagainya. Salah satu penyebab kematian Ibu adalah infeksi, di Indonesia Angka Kematian Ibu (AKI) yang disebabkan oleh infeksi semakin meningkat, pada tahun 2011 berjumlah 5,5\%, pada tahun 2013 meningkat menjadi 7,3\%. Hal ini menunjukkan infeksi pasca bersalin harus mendapat penanganan yang lebih serius (Kemenkes, RI. 2016).

Untuk mendukung penyembuhan luka mobilisasi dini harus segera dilakukan sesuai kondisi ibu, karena bermanfaat dalam meningkatkan fungsi paru-paru, memperkecil risiko pembentukan gumpalan darah, meningkatkan fungsi pencernaan, dan menolong saluran pencernaan agar mulai bekerja lagi (Cunningham, 2012).

Penelitian yang dilakukan oleh Kurnia Indriyanti Purnama Sari, di RSUD Bangil Pasuruan tahun 2013, menyatakan bahwa Mobilisasi dini dapat membantu ibu post SC mempercepat penyembuhan lukanya. Dimana semakin aktif ibu dalam melakukan mobilisasi dini maka semakin cepat terjadinya penyembuhan luka.

Cakupan penanganan komplikasi kebidanan di Sulawesi Tenggara cenderung menurun pada tahun 2015 yaitu 55,65\% sedangkan pada tahun 2016 yaitu 49,24\%. Kabupaten konawe cakupan penanganan komplikasi kebidanan sebesar 47,05\% (Profil Kesehatan Sulawesi Tenggara, 2017).

Rumah Sakit Dewi Sartika merupakan salah satu Rumah Sakit di Kota Kendari yang memberikan pelayanan kebidanan. Wawancara yang dilakukan kepada petugas kesehatan di Rumah Sakit Dewi Sartika, mobilisasi dini dilaksanakan pada semua pasien post operasi SC selama 1-7 hari, walaupun begitu, faktanya hari 1-3 pasien masih takut untuk melakukan mobilisasi seperti duduk. Banyak pasien yang mau melakukan mobilisasi di hari kelima post SC (Rumah Sakit Dewi Sartika, 2018).

Mobilisasi dini memiliki peran yang sangat penting terhadap proses penyembuhan luka. Kurangnya kesadaran ibu post SC melakukan mobilisasi dini memungkinkan penyembuhan luka terhambat. Oleh karena itu, perlu dilakukan penelitian dengan tujuan untuk mengetahui hubungan antara mobilisasi dini dengan proses penyembuhan luka sectio caesarea pada ibu post partum Di Rumah Sakit Dewi Sartika Kota Kendari tahun 2018".

\section{METODE}

Jenis penelitian yang digunakan adalah penelitian kuantitatif desain analitik menggunakan pendekatan studi cross sectional.Penelitian dilaksanakan pada bulan September sampai Oktober tahun 2018 di Rumah Sakit Dewi Sartika Kota Kendari. Teknik sampel yang digunakan adalah 
Accidental Sampling dan didapatkan 33 sampel. Analisis penelitian menggunakan uji chi-square. Instrumen yang digunakan adalah lembar observasi.

\section{HASIL}

Hasil analisa bivariat diperoleh hasil sebagai berikut :

Tabel 1. Hubungan Antara Mobilisasi Dini dengan Proses Penyembuhan Luka Sectio Caesarea pada Ibu Post Partum di Rumah Sakit Dewi Sartika Kota Kendari Tahun 2018

\begin{tabular}{|c|c|c|c|c|c|c|}
\hline \multirow{3}{*}{$\begin{array}{c}\text { Mobili } \\
\text { sasi } \\
\text { Dini }\end{array}$} & \multicolumn{4}{|c|}{$\begin{array}{l}\text { Proses Penyembuhan } \\
\text { LukaSectio Caesarea }\end{array}$} & \multicolumn{2}{|c|}{ Jumlah } \\
\hline & \multicolumn{2}{|c|}{ Cepat } & \multicolumn{2}{|c|}{ Lambat } & \multirow{2}{*}{$\mathrm{n}$} & \multirow{2}{*}{$\%$} \\
\hline & $n$ & $\%$ & $\mathrm{n}$ & $\%$ & & \\
\hline Baik & 15 & 45,5 & 6 & 18,1 & 21 & 63,6 \\
\hline Kurang & 4 & 12,1 & 8 & 24,3 & 12 & 36,4 \\
\hline Jumlah & 19 & 57,6 & 14 & 42,4 & 33 & 100 \\
\hline Palue & \multicolumn{6}{|c|}{0,03} \\
\hline
\end{tabular}

Hasil penelitian pada tabel 1 menunjukkan bahwa dari21 (63,6\%) responden yang melakukan mobilisasi dini dengan baik terdapat $15(45,5 \%)$ responden yang proses penyembuhan lukanya cepat, $6 \quad(18,1 \%)$ responden proses penyembuhan lukanya lambat. Sedangkan dari $12(36,4 \%)$ responden yang mobilisasi dininya kurang $4 \quad(12,1 \%)$ responden mengalami proses penyembuhan luka cepat dan $8 \quad(24,3 \%)$ responden mengalami proses penyembuhan luka lambat.

Hasil uji analisis chi-square diperoleh

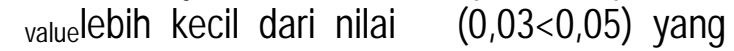
berarti $\mathrm{Ha}$ diterima yaitu terdapat hubungan antara mobilisasi dini dengan proses penyembuhan luka section caesarea.

\section{PEMBAHASAN}

Hasil uji analisis chi-square diperoleh $\rho_{\text {value }}$ lebih kecil dari nilai yang berarti Ha diterima yaitu terdapat hubungan antara mobilisasi dini dengan proses penyembuhan luka section caesarea. Penelitian ini sejalan dengan penelitian yang telah dilakukan Nur Rahma, dkk. di RSKD Ibu dan Anak Siti Fatimah Kota Makassar menemukan adanya hubungan mobilisasi aktif terhadap kesembuhan luka
( $\rho: 0,021)$, hubungan antara mobilisasi pasif terhadap kesembuhan luka ( $\rho: 0,005)$.

Penelitian ini mengobservasi proses penyembuhan luka luka SC pada tahap ploriverasi (3-4 hari). Tahap ploriverasi merupakan tahapan yang penting dalam penyembuhan luka karena pada tahap ini fibroblast secara cepat mensintesis kolagen dan substansi dasar sehingga sel-sel akan tumbuh dan membentuk jaringan. Responden yang mengalami proses penyembuhan luka section caesarea cepat sebanyak $19(57,6 \%)$ responden, lambat sebanyak $14 \quad(42,4 \%)$ responden.

Mobilisasi dini adalah salah satu faktor yang mendukung proses penyembuhan luka. Dimana mobilisasi dini merupakan proses aktivitas yang dilakukan setelah operasi dimulai dari latihan ringan diatas tempat tidur sampai dengan bisa turun dari tempat tidur, berjalan ke kamar mandi dan berjalan ke luar kamar (Brunner and Suddarth, 2013).

Mobilisasi dini sangat bermanfaat dalam proses penyembuhan luka, salah satunya yaitu mencegah potensi terjadinya trombosis dan tromboemboli, potensi terjadinya penurunan kemampuan fungsional, infeksi dan sebagainya. Infeksi merupakan salah satu penyebab kematian Ibu dimana infeksi terjadi akibat luka yang tidak mendapat penanganan tepat, baik luka post SC amupun luka bersalin normal. Pada tahun 2013 kematian ibu yang disebabkan oleh infeksi meningkat menjadi 7,3\% (Kemenkes RI. 2016).

Mobilisasi dini yang bisa dilakukan setelah operasi yaitu menggerakkan lengan, tangan, menggerakkan ujung jari kaki dan memutar pergelangan kaki, mengangkat tumit, menegangkan otot betis serta menekuk dan menggeser kaki. setelah 6-10 jam, ibu diharuskan untuk dapat miring kekiri dan kekanan mencegah trombosis dan tromboemboli, setelah 24 jam ibu dianjurkan untuk dapat mulai belajar untuk duduk.

Responden dalam penelitian ini menunjukkan mobilisasi dini yang baik sebanyak $21(63,6 \%)$ dari 33 responden. Hal ini terjadi karena responden mempunyai keinginan untuk dapat segera pulang dari rumah sakit sehingga hal tersebut memotivasi 
Ibu untuk segera melakukan mobilisasi sesuai dengan petunjuk dari tenaga kesehatan di rumah sakit. Motivasi juga diberikan oleh petugas kesehatan yang aktif memberikan pendidikan kesehatan kepada Ibu post SC mengenai hal-hal yang perlu dilakukan dalam menunjang proses penyembuhan luka. Selain itu, petugas kesehatan membantulbu melakukan mobilisasi dini.

Untuk 12 (36,4\%) responden yang kurang melakukan mobilisasi dini disebabkan karena faktor psikologis. Adanya rasa takut akan luka akan berdarah atau jahitan luka akan putus jika melakukan banyak pergerakan. Terlebih lagi pada hari ke 3 masih sering terasanya nyeri yang bisa jadi menyebabkan motivasi Ibu untuk melakukan mobilisasi menurun.

Proses penyembuhan luka masing-masing individu bervariasi, namun mobilisasi dini harus tetap dilakukan pasca operasi SC mengingat banyaknya manfaat yang diperoleh. Tanpa mengabaikan faktor pendukung lainnya seperti nutrisi, oksigenasi, penggunaan obat dan sebagainya.

\section{KESIMPULAN DAN SARAN}

Ada hubungan antara Mobilisasi Dini dengan Proses Penyembuhan Luka Section Caesarea pada lbu Post Partum di Rumah Sakit Dewi Sartika Kota Kendari tahun 2018.

Pihak Rumah Sakit Dewi Sartika diharapkan meningkatkan health education mengenai pentingnya mobilisasi dini untuk penyembuhan luka SC sehingga memotivasi pasien untuk segera melakukan mobilisasi dini setelah operasi.

\section{REFERENSI}

Brunner and Suddart. 2013. Keperawatan Medikal Bedah Ed. 12. Jakarta: EGC.

Cunningham, et al. 2012. Obstetri Williams. Jakarta : EGC.

Dines Kesehatan Sultra. 2017. Profil Kesehatan Sultra.

Kemenkes, RI. 2016. Profil Kesehatan Indonesia. Jakarta.

Profil Rumah Sakit Dewi Sartika Kota Kendari. 2018.

Sari Indriyanti Purnama Kurnia. 2013. Efektivitas Mobilisasi Dini Terhadap
Penyembuhan Luka Post Sectio Caesarea. Jurnal Keperawatan \& Kebidanan, Stikes Dian Husada Mojokerto. Hal. 74-80.

Wiknjosastro. 2011. IImu Kebidanan. Jakarta: Yayasan Bina Pustaka Sarwono Prawirohardjo.

World Health Organization. 2018. Intrapartum Care For a Positive Childbirth Experience. Geneva: World Health Organization. Licence : CC BY-NC-SA 3.0 IGO. 